\title{
Investigating the Working Environment and the Hindrance Faced by Street Hawkers in Bangladesh: An Empirical investigation in Dhaka City
}

\author{
Istihak Rayhan $^{1^{*}} \quad$ Asif Tanvir $^{2} \quad$ Barin Mazumder ${ }^{3}$ \\ 1.Lecturer at the Department of Economics, Bangabandhu Sheikh Mujibur Rahman Science \& Technology \\ University, Gopalganj, Bangladesh. \\ 2.Studies in the Department of Economics, Jahangirnagar University, Dhaka, Bangladesh. \\ 3.Studies in the Department of Accounting \& Information Systems, Faculty of Business Studies, Bangladesh \\ University of Professionals, Dhaka, Bangladesh.
}

\begin{abstract}
The working condition of street hawkers in Dhaka city is not a pleasant scenario. This study is conducted to investigate their working condition highlighting corruption, the threat of e-commerce, lack of education, exposure to noise and people's perception of them. Several field surveys on Dhaka city have been conducted based on a well prepared questionnaire covering six places and we collected data on the noise level (Levels of sound were taken through a mobile app from 5 busy places of the city where street hawking prevails), amount of bribe, level of education and price variation with the online shop. We also conducted an online survey to determine people's perception of street hawkers. We find that $59.8 \%$ people are not aware of the condition the hawkers work in, where $57.4 \%$ prefer to shop from online shops over street hawkers and $42.6 \%$ were in favor of shopping from the street hawkers, $86.1 \%$ opined that they are in favor of the eviction of the hawkers and only $13.9 \%$ were in against the eviction. We also found that on average the hawkers pay about 100-150 taka per day as extortion money, the average level $(\mathrm{Db})$ of sound in Mirpur, Newmarket, Motijheel, Gulistan, Savar are respectively $70.4,71.2,77.2,71$, and $70.6(\mathrm{Db})$.
\end{abstract}

Keywords: Street hawkers, working conditions, exposure to noise, Dhaka city, Bangladesh

DOI: $10.7176 / \mathrm{JESD} / 10-2-09$

\section{Introduction}

As a profession, Street hawking has been carried out all along in the known history and it has been an integral part of both urban and rural culture of Bangladesh. A street vendor is a person who sells something in the street, either from a stall or van or with their goods laid out on the sidewalk. A street vendor is broadly defined as a person who offers goods and services for sale to the public without having a permanent built-up structure but with a temporary static structure or mobile stall. Street vendors offer products and services by occupying space on the pavements or other public or private areas. In search of a better existence, people are gathering from rural areas in the cities for lack of gainful employment coupled with poverty. But they are not in a position to get a better paid, secured employment in the formal sector and they have to stay for work in the informal sector (Suraiya \& Noor, 2012).

Most street vendors provide the main source of income for their households, bringing food to their families and paying school fees for their children. Street vendors are a large and very visible workforce in cities, yet it is difficult to accurately estimate their numbers.

In Bangladesh, street hawkers aren't recognized as the legal workforce. So, the working condition of street hawkers isn't a concern for the government but the government isn't sitting idle either. Renovation \& eviction; both roles are played by the government to ensure a better and healthy living city. Many renovation steps went in the wrong direction for market syndicates, local goons \& corrupt law enforcers. It isn't like the only reasons that held back hawker renovation. Most of the time it's the hawkers itself, that doesn't want to lose their hawking position just by a verbal assurance from officials, though there are passed plans of infrastructures to move enlisted hawkers to renovated positions. Government evicts street hawkers every now and then to minimize the number of hawkers and especially to ease traffic jam. Though a leader of Bangladesh Hawkers Union (BHU) stated that, the contribution of hawkers to the economy can't be denied. A majority of people from lower and middle- income groups buy things from the pavements on the way back home from work. (Hawkers seek rehab law from the government, 2017).

The working condition of street hawkers is quite mundane in Bangladesh. They are subject to the unhygienic and unhealthy condition due to environmental hazards and noises. Whether a person having a shop in a shopping complex can enjoy several benefits but a street hawker is deprived of them. As they do not form a part of Gross Domestic Product (GDP), the government are sort of reluctant to look what kind of problems they are facing.

The street vendors of Bangladesh are more vulnerable than those in the neighboring countries due to 
poverty, lack of space for vending and lack of awareness about their rights (Nahar, 2016).

Street Vendors faces many difficulties as they are vulnerable population, who are neither protected by the government, NGOs, labor union nor by any labor law. They have deprived by-laws made by the government in respect of labor union (Diwakar \& Anand, Socio-Economic Study on Women Street Vendors, 2014).

\subsection{Threat of E-Commerce}

Recently a new trend is going, which the great emergent of online is shopping. Thanks to Facebook, and also the easy and cheap access to the internet, people nowadays leaning towards online shopping more than ever. Mainly the driving force of this online business is there is no need for any real shop, no need of keeping extra inventories, as they buy product per order basis, and customer demand. Most of the E-Commerce site owners are a freelance businessman with another job. But, how it becomes a threat to the hawker market need to explain. The underlying reason is, most of the products sold in online shops are also available in the hawker market. Where a businessman in a hawker market has to maintain many business relationships and real-time risks like eviction, bad weather, bribe and most of all, they usually buy wholesale products by a large amount, whether it sales or not. If they don't buy large quantity, they won't be able to cover up their fixed cost and will be unable to earn profit. On the contrary, online shop owners don't have to deal with most of the problems faced by street hawkers. They don't have any issues like getting evicted. Their parcel service doesn't tamper with the weather condition, no bribes to be given and they buy products per order. Though it costs more, an online shop sells the product with 80 to more than 100 percent profit margin.

Online shopping has a significant negative impact on retailers and street vendors. Online shopping is a form of electronic commerce whereby consumers directly buy goods or services from a seller over the internet without an intermediary service. Online shopping has become a trend and the new mode of purchasing. There are around 1000 s of online marketing enterprises selling cosmetics, clothes, shoes, accessories, vitamin supplements, etc. literally the entire range of consumer items. The trend is very clear; retail shop demand will fall and even shrunk. Online shopping is indeed having an adverse impact on the retail sector (Diwakar \& Anand, Socio-Economic Study on Women Street Vendors, 2014).

It seems impossible, but this is what is happening. People who buy from online shops are those who can't manage time to go out and buy something in person. Some people prefer leisure than going out and shop in their free times. Again, most online shoppers actually buy products which they think unique and they know unique products aren't sold in all hawker markets. So, they have to rely on the online shops. Some people don't have the real price idea of a thing they want to buy so that they usually rely on online shops than bargaining in a street market. People outside of the capital cities are the main customers of an online shop as they can't find a quality product in local markets and street markets. These are some reasons behind the emergence of E-Commerce in Bangladesh. Involvement of people in e-commerce has increased significantly and the growth rate is impressive. The emerging scenario E-commerce in Bangladesh is presented in Table-1.

Table-1: Overview of the recent situation of E-commerce in Bangladesh

\begin{tabular}{|c|c|}
\hline Websites & 1000 \\
\hline Facebook Page & 15,000 \\
\hline People involved & 50,000 \\
\hline Transaction Worthiness & More than 1000 crore \\
\hline Daily Parcel delivered & 30,000 \\
\hline Daily Order & $2,00,000$ \\
\hline Daily Transaction & $3-4$ Crore \\
\hline Cash on delivery & $85 \%$ \\
\hline
\end{tabular}

(Source: e-CAB)

Table-2: E-Commerce Growth Rate

\begin{tabular}{|c|c|c|c|}
\hline Year & Q1-Q2 & Q2-Q3 & Q3-Q4 \\
\hline 2014 (Recorded) & $27 \%$ & $39 \%$ & $51 \%$ \\
\hline 2015 (Predicted) & $60 \%$ & $72 \%$ & $79 \%$ \\
\hline 2016 (Predicted) & $85 \%$ & $95 \%$ & $100 \%$ \\
\hline
\end{tabular}

(Source: e-CAB)

Street hawker market consists of millions but still considered an informal part of the economy. Though most of the people ( $61 \%$ of the respondents) do shop from the street hawker they have an almost unified opinion ( $86.1 \%$ of the respondents) about their eviction. But before evicting we have to think about their rehabilitation on the same profession or somewhere else. According to our field survey result, $40 \%$ of the street hawkers are educated below primary level. Which isn't a minimal level of education for a person to get a job. From the 
findings, a vital sign can be seen. It is the growing interest of the online market among the general people. Most of the people we have surveyed were from the young generation. The mean age was 24.91. There are some reasons why they are getting reluctant to shop from the street hawkers. The most underlying reason is the traffic jam in the city. Most of the people from the young generation do not find it appealing to buy from the street as they have to endure a traffic jam in order to reach. According to a report published in Dhaka Tribune, the average speed of this city is the only $7 \mathrm{kmph}$. It has reduced to this level from $21 \mathrm{~km} / \mathrm{h}$ in the past 10 years. It eats up 3.2 million working hours a day. So to avoid the hassle they are getting less interested. Availability of debit and credit card is also a vital reason as many people prefer to buy from home rather than going to the hawkers. The online shops are taking the advantage of the increase in lifestyle and purchasing power of the people by charging a price which can be 2-3 times more than the street. The citizens are now preferring time over money day by day. In order to spend more time with the family and to avoid a hassle, they are getting inclined to buy from online. If things are going in this way in the long run people will be more and more dependent on online shops. This is resulting in a decrease in the consumer surplus also.

\subsection{Corruption}

Hawkers face corruption from the starting day of their business. Street hawkers aren't recognized in the economy of Bangladesh. So, this is capitalized by influential local personals. Hawkers pay extortion money to have a shop space on the streets. This also covers the security of not getting evicted, electricity bill and more facilities. The places occupied by street hawkers belong to the government. So, by renting public places, influential personals are increasing the scope of corruption. By having no recognition of the street hawkers, the massive transaction of money has no record to the government. This way the government is losing a handsome amount of taxes too.

"Around TK 850 crore is extorted from hawkers every year, mostly by police to be followed by criminals, city corporation officials and political party cadres, claimed hawker leaders" (Islam, 2015). Wishing anonymity, a tea stall owner in Motijheel Shapla Chattar area said he pays Tk 100 daily to a lineman from his sale of around Tk 800. By selling around 130 cups of tea, he makes a profit of around Tk 300 . To earn the extortion money, he has to sell a cup of tea at Tk 6, which he could have sold at Tk 5. He thought that the lesser price of tea would have hiked his sales. "There are over 5 lakh hawkers in the country and each of them on an average pays Tk 50 every day to linemen, who are private agents of extortionists," MA Kashem, president of Bangladesh Hawkers Federation (BHF), told a press conference at the Paltan office of Bangladesh Photojournalists' Association in the capital" (Islam, 2015)

It can be found from a local newspaper that about 4500 to 5000 hawkers have set up their shop in Motijheel and nearby areas. This became a source of money earning opportunity by the extortionists who have been collecting average TK 6 Lakh each day. About 1.5 crore TK revenue each month is lost by the hawkers by giving this extortion money (Rabbi, 2017)

Of the shops, 3,500 are in Gulistan, Baitul Mukarram and Paltan areas, and they pay Tk 28 lakh in "extortion money" a day, claimed Kamal Siddiqui, president of Bangladesh Chhinnamul Hawkers Samity (It's all for extortion, 2016)

\subsection{Education and Street Hawkers}

The level of education is one of the most crucial variables which dictates a person's lifestyle and in most cases the employability of that person. In our society surviving without a certain level of education is a matter of miracle and it involves sheer luck. People with education has a far better edge of surviving than those of who does not. Without a minimum level of education, it is really hard to survive. Even if someone wants to do business he or she should have a level of education which will give a better understanding of business. In Dhaka city, we see that the level of education among the street hawkers are not that sound which hinders the process of finding different jobs where an educational background is a must. In the case of the street hawkers, the educational condition is really down to the mark. This doesn't give them the chance for any employment. So often without finding an alternative, they take this profession.

\subsection{Perception about Street Hawkers}

On the context of street hawking, people's perception is a mixture of supportive and negative. Negative perception is at a greater extent towards street hawkers but there is some positive perception too according to our field survey. People perceive from many sources. There are explicit experiences and common beliefs. What we have found is people don't see the other side of the coin. It's human nature to think of personal advantage over others. People face scarcity of walkway and narrow roads to drive through due to street shops which are generally situated on footpaths.

On the other hand, street hawkers do hawking because they have nothing to do except hawking to earn their living. If they had alternatives, the majority of street hawkers would leave this profession. The situation of a street hawker has never been easy. They have to deal with a lot of problems to cope in there. 


\subsection{Exposure to Continuous Noise}

Like water and air pollution, sound pollution in Dhaka metropolitan has become a severe issue. According to the Department of Environment (DOE), Bangladesh: the standard noise level in the residential area is $40 \mathrm{~dB}-50 \mathrm{~dB}$. In the commercial area the standard noise level is $60 \mathrm{~dB}-70 \mathrm{~dB}$. Most of the street hawkers are situated in residential and commercial areas. Due to sound pollution, this noise level exceeds well above the set standard of Department of Environment (DOE), Bangladesh. Table-3 shows some adverse health effects on street hawkers for sound pollution.

Table-3: Adverse health effects on street hawkers for sound pollution

\begin{tabular}{|l|l|l|l|l|l|}
\hline Area & No. of Person & $\begin{array}{l}\text { Hearing } \\
\text { Impairment }\end{array}$ & Blood Pressure & Agitation & $\begin{array}{l}\text { Task } \\
\text { Performance }\end{array}$ \\
\hline Commercial & 30 & 22 & 8 & 18 & 17 \\
\hline Residential & 30 & 20 & 25 & 27 & 16 \\
\hline Industrial & 30 & 21 & 27 & 17 & 17 \\
\hline Silent & 30 & 20 & 18 & 20 & 22 \\
\hline Mixed & 30 & 20 & 14 & 18 & 14 \\
\hline
\end{tabular}

Source: (Ahmed \& Rahman, 2015)

For street hawkers, noise-induced hearing impairment is almost same in all the areas. But when it comes to no auditory effects like blood pressure, the percentage fluctuated largely. Although only $27 \%$ of surveyed hawker blamed noise for their blood pressure in commercial zones, the rate is exact 90 in term of industrial areas. Another non-auditory effect namely agitation is severe in residential areas, yet other areas have quite a similar result. Task performance is greatly hampered for the hawkers in silent zones. The most significant feature of this graph is, at least $60 \%$ of surveyed hawkers is suffering from noise-induced hazards in silent zones. (Ahmed \& Rahman, 2015)

\section{Literature review}

The definition of street hawkers can be well understood according to the National Policy on Urban Street Vendors, street hawkers are identified as self-employed workers in the informal sector. What we find is that they have to sell goods and services by occupying streets without any permanent built-up structure (Ministry of Urban Employment and Poverty Alleviation, 2006). By studying the literature (Dendukuri, 2014), it can be said that from the very beginning street hawking has been playing a significant role in the informal economic sector. The number of people depending on this sector is very large. In most of the metropolis of India, it is regarded as the prime way of living for the urban poor people. A fairly high proportion of vendors were once workers in the formal sector and they had taken to street vending after they lost their jobs. This proportion is higher in cities like Kolkata (50percent), Mumbai and Ahmadabad (30 percent). A study by SEWA in Ahmadabad notes that half the laid-off textile workers in Ahmadabad have taken to street vending. In search of employment, most of the street hawkers migrate from rural areas or from small towns. In the very competitive cities, they often fail to get jobs. Thus they choose street hawking. In Delhi, the feminist journal Manushi conducted a study on street vendors which showed the stark reality of how these people are exploited and harassed by the authorities (The Hindu Delhi, June 26, 2001).

According to (Bhowmik, 2001), various studies have already confirmed the fact that street hawkers comprise one of the most marginalized sections of the urban poor. Notwithstanding the fact that they play a very unique role in the urban economy, providing necessary goods, which are largely both durable and cost-effective, to average income-earning households at cheap and affordable rates. Also, they always have to serve their consumers need, who happens to be coming from the poor sectors (Bodhikong \& Boonyarit, 2003). As we study more about them, some factors came before us which are some variables of the street vendor's sufferings. Due to fluctuation in market price, insecure and irregular employment their income is often minimal subject to fluctuating sales. Another alarming reason is due to the bribe they are forced to pay daily which might be around 10-20 percent of their daily income (Diwakar \& Anand, Socio-Economic Study on Women Street Vendors, 2014). Hawkers sell goods at low prices (Bhowmik, 2005) and street vendors face unique kinds of livelihood risks because of the legal, physical, and socio-cultural environment in which they work. The most pressing and ongoing risk for many street hawkers is the possibility that local government authorities will forcibly remove them from the streets or confiscate their merchandise. This risk of eviction often increases prior to elections, mega-events, or efforts to beautify historic city centers. Just like formal business operators, street vendors are less efficient in unstable institutional environments where rules are irregular and unpredictable (Bhowmik, 2010). Street vendors face more routine occupational hazards as well. They need to lift and haul heavy loads of goods to and from their point of sale each day. The work environment lacks proper infrastructure, such as clean running water, toilets, and solid waste removal (Khairuzzaman et al., 2014)

The level of education among the street hawkers is comparatively low and in the case of a majority, level of education varied between grades 5 and 8 (Khairuzzaman et al. 2014). The increasing growth rate of child 
hawkers in Nigeria has become worrisome. The investigation of the study has brought to light that parents 'levels of education, parents 'occupations and the sizes of the family were significantly related to the problem of child hawkers in the study area. The study recommends intensified enlightenment programs on the problem of child hawkers, positive and genuine commitment by the government, mass, free and compulsory education, and a serious fight against poverty through poverty alleviation and eradication programs by the governments (Matthias \& Dada, 2013).

Women comparatively face much more problems in street vending rather than men. Women are generally affected by crimes like eve-teasing, sexual harassment, rapes, etc. Street vending is not an easy task for women (Diwakar \& Anand, 2014), and the basic problems of women street vendors is insecurity and uncertainty as their profession is considered illegal, but according to government of India assessment done in 2004 shows around $2.5 \%$ of local poor urban population survive by working in this occupation. If the government provide the license to street vendors, they can be protected by harassment and eviction by local authorities and local police (Diwakar \& Anand, 2014).

The laws of Netherlands do not permit construction of houses in areas where 24-hour average noise levels exceed 50dB. In Great Britain and India, the Noise Act empowers the local authorities to confiscate noisy equipment and to take legal action against people who create excessive noise at night. Several countries are also investing in newer technology, which can curtail noise pollution (Singh \& Davar, 2004).

\section{MATERIALS AND METHODS}

\subsection{Study Area and sample size}

The study was carried out in five prime areas of Dhaka city, the capital of Bangladesh. The areas are New Market, Mirpur, Motijheel, Gulistan, and Savar. The sample size was taken randomly in a purposive manner. 80 street hawkers from the five study areas were interviewed. To achieve the perception towards street hawkers, we collected responses from 122 general people. Data were collected from July 2018- November 2018.

\subsection{Objectives of the Study}

The objective of this study falls into two part.

1. To show the hindrances faced by the street hawkers in terms of the emergence of e-commerce, extortion money, and noisy work environment.

2. The people's perception of the street hawkers based on preference, satisfaction, eviction, sympathy, manner and overall condition.

\subsection{Method}

Basically 8 questions were constructed to find out about the perception of the general people about the street hawkers, where 122 responses were taken. We used the Statistical Package for the Social Sciences (SPSS) version 20 to analyze the responses.

We have also done a field study where we asked 80 street hawkers about their education level and most importantly the amount of extortion money they give. Different noise level was taken in the decibel scale from 5 key hawking point of the city. The areas are Mirpur, Newmarket, Motijheel, Gulistan and Savar bus stand.

\section{Findings and Results}

\subsection{Education}

Table-4: Education level of studied 80 street hawker

\begin{tabular}{|c|c|c|}
\hline Educational Background & Number of People & Percentage \\
\hline Below Primary & 32 & $40 \%$ \\
\hline Class 5-8 & 21 & $26.25 \%$ \\
\hline Class 8-10 & 14 & $17.5 \%$ \\
\hline SSC & 7 & $8.75 \%$ \\
\hline HSC & 4 & $5 \%$ \\
\hline More than HSC & 2 & $2.5 \%$ \\
\hline Total & 80 & $100 \%$ \\
\hline
\end{tabular}


Figure-1: Histogram-based on the Table-4

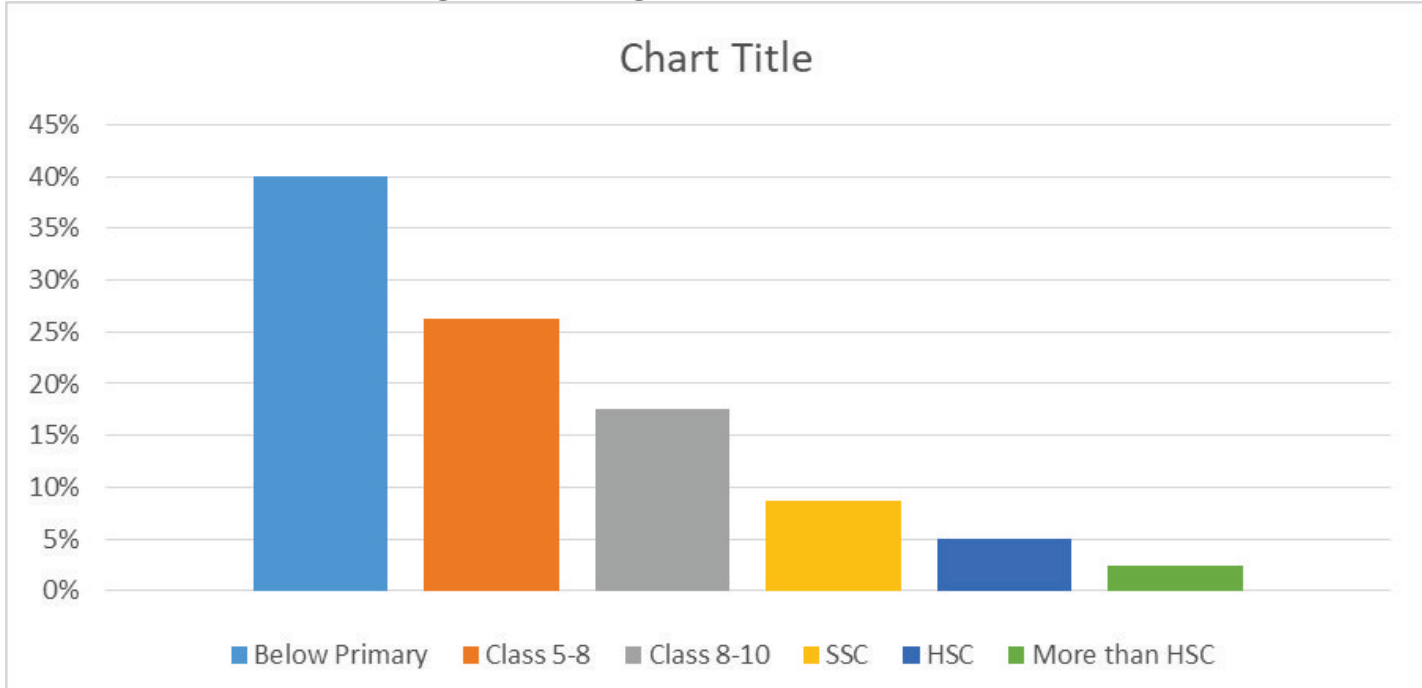

In our survey of 80 street vendors from different parts of Dhaka city, we can see that there are roughly 5\% hawkers who passed HSC and nearly 9\% hawkers are SSC passed. A big chunk of people belongs to the below primary level covering $40 \%$. 26.25\% street hawkers studied up to class 8 . So the survey indicates that the level of education is not dominant among street hawkers which deter them from finding jobs elsewhere.

\subsection{Extortion Money Given by Different Types of Hawkers}

The most controversial topic on street hawker is if they pay the bribe or not to hawk in a local place. Though it's an open secret. If we think of a well-constructed shop, a shop owner rents the shop space for an amount of money. The tenant doesn't get it for free. If the shop owner runs own business in the shop, then the owner has to bear the implicit cost of not renting the shop space. A hawker's shop and a rental shop in a market have one thing in common that is space. So the local power won't just undergo its space for free. If a shop's placing is good it definitely can sell more. It's true for hawker's shop also. It became the most challenging part to obtain the information about the amount of bribe street hawkers pay.

In our field study, we observed a significant difference between different types of street hawkers in the same area. The lack of responsiveness led this study a complicated one but we managed to obtain data from the key areas of Dhaka city. Collectors or middlemen take the money on a shift basis, not altogether always. Street hawkers pay to the middleman daily to stay on the assigned location. The following table illustrates the extortion rate of different vendors in some key areas of Dhaka city.

Table-5: Extortion rate of different hawkers in key areas of Dhaka city

\begin{tabular}{|c|c|c|}
\hline Type of Seller & Area & Extortion Rate Per Day \\
\hline Readymade Garment Seller & Savar Bus Stand & $100-150$ \\
\hline Ornament Seller & New Market & $100-150$ \\
\hline Food Cart & New Market & $50-250$ \\
\hline Accessories Seller & Gulistan & 200 \\
\hline Accessories Seller & Mirpur & $100-200$ \\
\hline Snacks Seller & Mirpur & $40-50$ \\
\hline Fruit Seller & Mirpur & 0 . \\
\hline
\end{tabular}

So, in every area, the average extortion money is between 100-150 taka. This rate varies on holidays and working days. As there is no official data of this transaction, it's not known how much is collected daily through the end of the month.

\subsection{People's Perception of Street Hawkers}

We take data from 122 respondents, where 77 (63.1\%) were male and 45 (36.9\%) were female. For evaluation, we constructed seven questions.

I) Do you prefer to shop for street hawkers?

Our first question was about the preference of shopping from street hawkers. We found from the survey that 48 $(39 \%)$ out of 122 respondents don't prefer to shop from the street hawkers and the rest $74(61 \%)$ prefer to shop from the hawkers. 
II) Are you satisfied with the quality versus price ratio of street products?

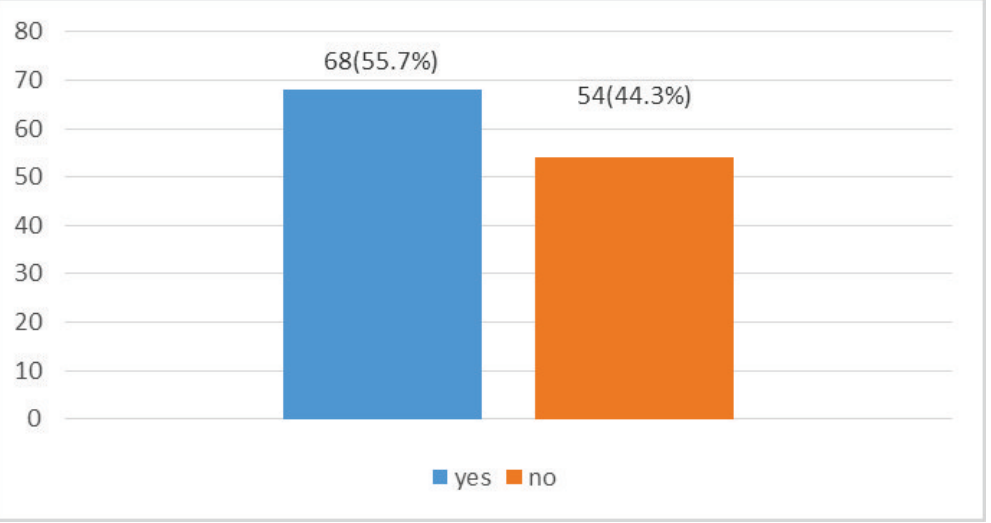

Our second question was about the quality versus price ratio of street products. The gap of the satisfactory level is not so high between the qualities versus price ratio. $68(55.7 \%)$ said they are satisfied with the quality they get for the price and $54(44.3 \%)$ said that they are not that satisfied.

III) Street hawkers need to be evicted from street to ease traffic jam and increase walking area?

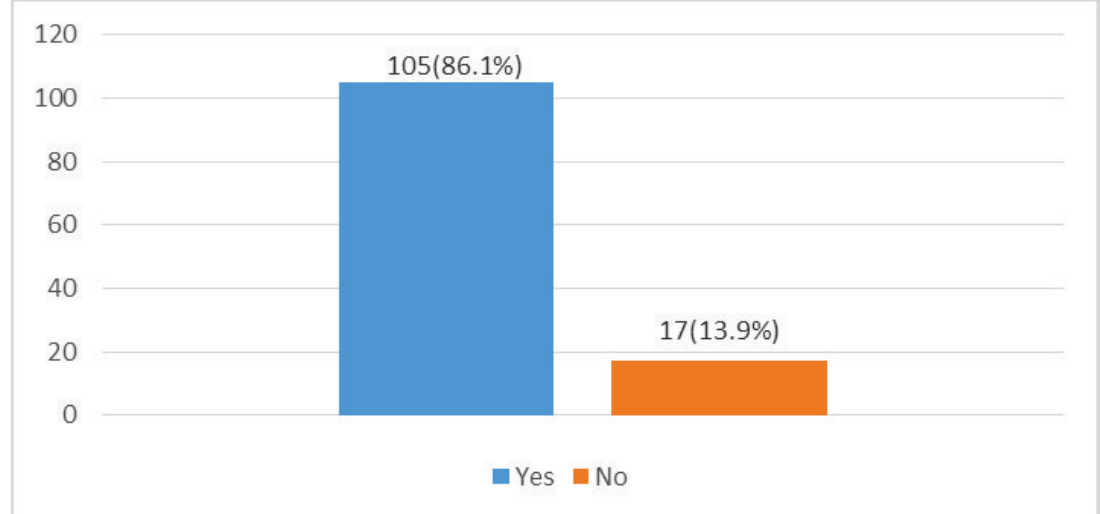

Our third question was about the eviction of the street hawkers. The result here shows a direct opposite finding against the previous two questions. Whereas most of the people are satisfied and do shop from the street hawkers but the majority of them, $105(86.1 \%)$, have been wanted the eviction of the hawkers. The underlying reason for this type of findings is that most of them think, shops in the street are highly responsible for the traffic jam in these areas and these shops actually, destroy the friendly environment of the street. So, for a better city life these types of shops should be evicted. 
IV) Are you aware of their working condition?

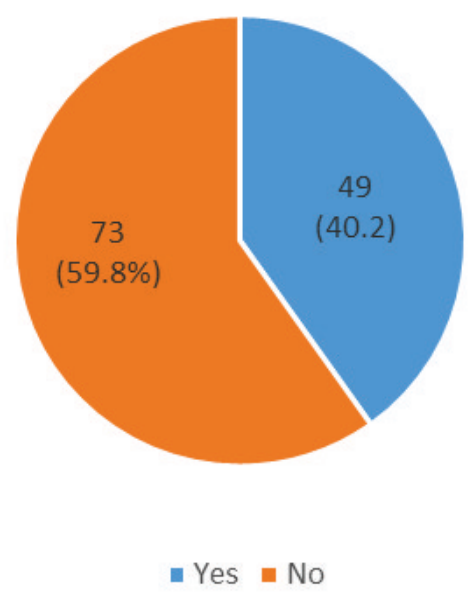

Our fourth question was, whether they are aware of the working conditions of the street hawkers. Among 122 respondents, $49(40.2 \%)$ told that they were aware of the working condition of the street hawkers and $73(59.8 \%)$ did not know much or care about their working condition.

V) Do you prefer online shopping over street hawkers?

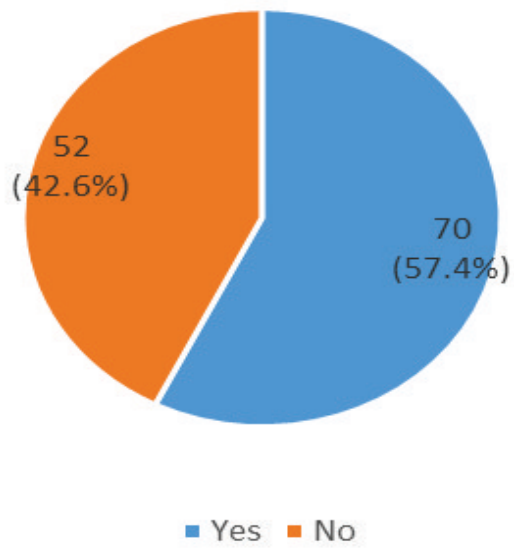

Our fifth question was about comparison between online shopping and street hawkers. From our data we found that $70(57.4 \%)$ preferred online shopping over street hawkers. It is a major finding that though in previous question most of them told they shop from street hawkers, but when it came to the matter of preference between online shopping and street hawkers, the majority of them prefer online shop over street hawking. We tried to identify the underlying reason for this type of preference. As most of the respondents were young age people, they feel good to shop from online rather than hawker because of ongoing new tradition and as it saves our valuable time. 
VI) How much sympathetic you are to their overall condition?

\section{How much sympathetic you are to their overall condition?}

\section{2 responses}

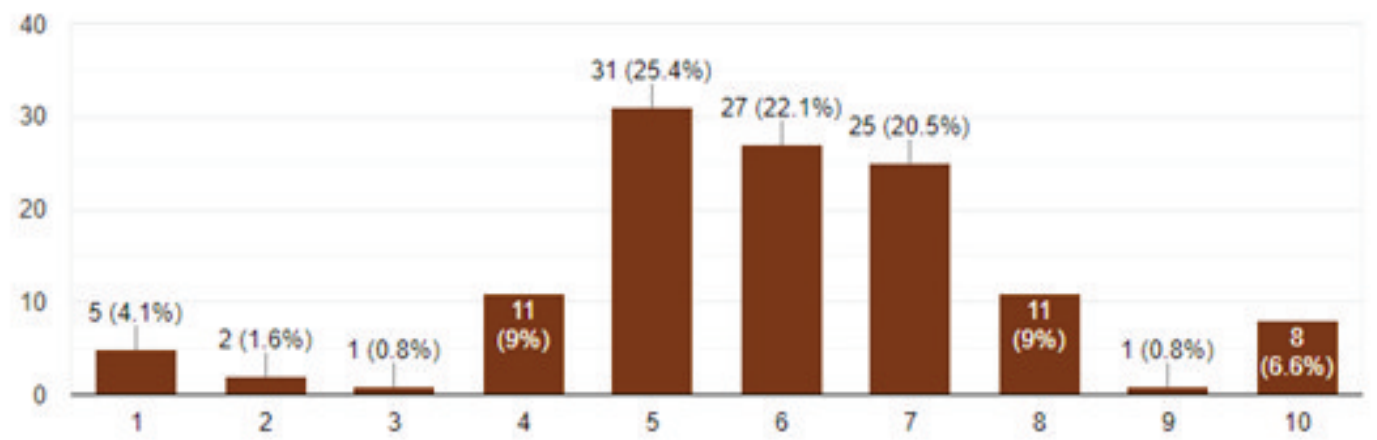

Mean value, $\mu=5$

Significance interval, $\alpha=0.05$

\begin{tabular}{|c|c|c|c|c|}
\hline \multicolumn{5}{|c|}{ One-Sample Statistics } \\
\hline & $\mathrm{N}$ & Mean & Std. Deviation & Std. Error Mean \\
\hline sympathy & 122 & 5.9508 & 1.90195 & .17219 \\
\hline
\end{tabular}

\begin{tabular}{|c|c|c|c|c|c|c|}
\hline \multicolumn{7}{|c|}{ One-Sample Test } \\
\hline & \multicolumn{6}{|c|}{ Test Value $=5$} \\
\hline & \multirow[t]{2}{*}{$\mathrm{T}$} & \multirow[t]{2}{*}{ Df } & \multirow[t]{2}{*}{ Sig. (2-tailed) } & \multirow[t]{2}{*}{ Mean Difference } & \multicolumn{2}{|c|}{$95 \%$ Confidence Interval of the Difference } \\
\hline & & & & & Lower & Upper \\
\hline sympathy & 5.522 & 121 & .000 & .95082 & .6099 & 1.2917 \\
\hline
\end{tabular}

Here, $\mathrm{p} \leq 0.05$ so the test is significant and the sample is significantly different from $\mu=5$.

Hence people who were surveyed had a sympathetic position about street hawkers.

VII) How much you are satisfied with their manner?

Our last question was whether people are satisfied with the manner or behavior of street hawkers during trading time.

\section{How much you are satisfied with their manner?}

\section{2 responses}

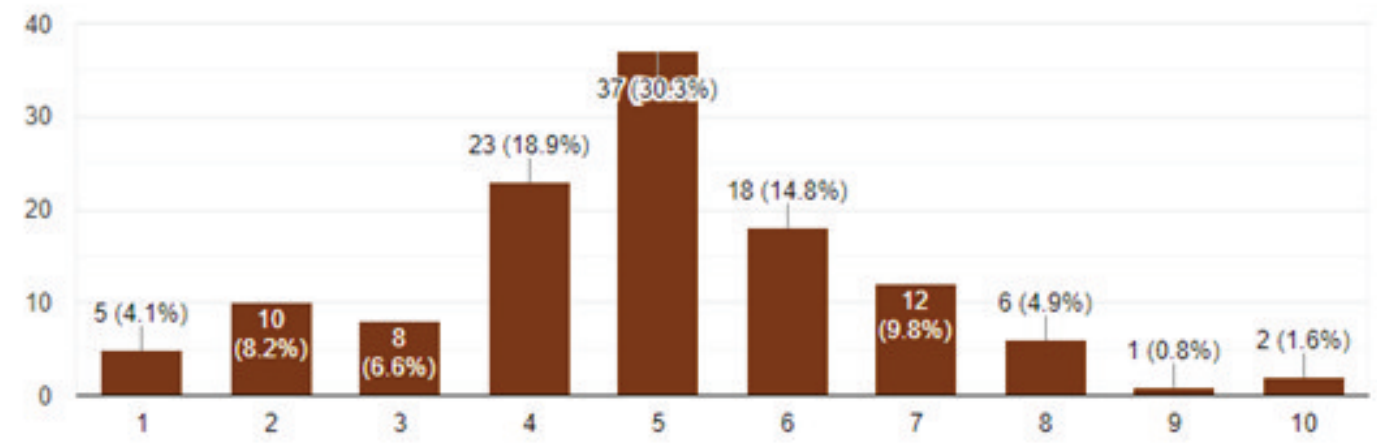

Mean value, $\mu=5$

Significance interval, $\alpha=0.05$ 


\begin{tabular}{|c|c|c|c|c|c|c|}
\hline \multicolumn{7}{|c|}{ One-Sample Statistics } \\
\hline & & $\mathrm{N}$ & Mean & \multicolumn{2}{|c|}{ Std. Deviation } & Std. Error Mean \\
\hline Manner & & 122 & 4.8770 & \multicolumn{2}{|c|}{1.83887} & .16648 \\
\hline \multicolumn{7}{|c|}{ One-Sample Test } \\
\hline & \multicolumn{6}{|c|}{ Test Value $=5$} \\
\hline & \multirow[t]{2}{*}{$\mathrm{T}$} & \multirow[t]{2}{*}{ df } & \multirow[t]{2}{*}{ Sig. (2-tailed) } & \multirow[t]{2}{*}{ Mean Difference } & \multicolumn{2}{|c|}{$95 \%$ Confidence Interval of the Difference } \\
\hline & & & & & Lower & Upper \\
\hline Manner & -.739 & 121 & .462 & -.12295 & -.4525 & .2066 \\
\hline
\end{tabular}

Here, $\mathrm{p} \geq 0.05$ so the test is not significant and the sample is not significantly different from $\mu=5$.

So the people who were surveyed had neither a significantly favorable or unfavorable perception about the manner of the street hawkers.

4.4 Exposure to Continuous Noise

\begin{tabular}{|c|c|c|c|}
\hline Study Area & Data no & Measured dB & Average dB \\
\hline \multirow{5}{*}{ Mirpur } & 1 & 71 & \multirow{5}{*}{70.4} \\
\hline & 2 & 73 & \\
\hline & 3 & 68 & \\
\hline & 4 & 69 & \\
\hline & 5 & 71 & \\
\hline \multirow{5}{*}{ New Market } & 1 & 65 & \multirow{5}{*}{71.2} \\
\hline & 2 & 74 & \\
\hline & 3 & 76 & \\
\hline & 4 & 68 & \\
\hline & 5 & 73 & \\
\hline \multirow{5}{*}{ Motijheel } & 1 & 79 & \multirow{5}{*}{77.2} \\
\hline & 2 & 74 & \\
\hline & 3 & 82 & \\
\hline & 4 & 83 & \\
\hline & 5 & 68 & \\
\hline \multirow{5}{*}{ Gulistan } & 1 & 70 & \multirow{5}{*}{71} \\
\hline & 2 & 66 & \\
\hline & 3 & 71 & \\
\hline & 4 & 74 & \\
\hline & 5 & 74 & \\
\hline \multirow{5}{*}{ Savar } & 1 & 66 & \multirow{5}{*}{70.6} \\
\hline & 2 & 73 & \\
\hline & 3 & 78 & \\
\hline & 4 & 67 & \\
\hline & 5 & 69 & \\
\hline
\end{tabular}

Here the findings show that the street hawkers in these areas are exposed to the average noise level of 70.04 $\mathrm{dB}-77.02 \mathrm{~dB}$. The hawkers are usually exposed to this kind of noise for more than 10 hours. This implies a serious health hazard leading to mental stress, psychological damage and partial deafness. This level of sound might not impair a person just by listening but by continuously being exposed to this noise daily for many years' leads to an ill physical and mental condition. Many times the level exceeds the average decibel level of noise. In Mirpur, the highest level of noise we found was 89 decibels. In Motijheel it's 82, in New Market 83, In Gulistan 87 and in Savar it's 82. Due to the continuous honking of vehicles and loud mikes, the noise level increases beyond tolerance. This increase in level is not a seldom case. It happens all the time making the whole working condition a lot more complicated.

\section{Conclusion}

The average extortion money for a street hawker is between 3000-4500 Taka per month, which has a significant negative impact on their earnings and the overall standard of living. Moreover, they are working continuously in an unfavorable working conditions, which may cause their physical and psychological disorder. Usually they have to work in a place where average exposed to noise is 70-77 DB, which is significantly high. Street hawkers are an integral part of our society. Very few people or organizations think about their betterment or rehabilitation. They don't get much support from the government, rather they are facing many threats. This study does not reflect on the issues like how the street hawkers are detrimental to society rather it reflects some facts why this 
profession is facing some hindrances. So we believe, some necessary steps should be taken to improve their conditions. The government should strictly regulate the e-commerce based business about the price and the quality. In this era of internet and connectivity, usage of e-commerce is a must, sometimes comfortable too. This study is not against that. But it is a matter of concern for the working class and middle-class people, as the profit margin of e-commerce is much higher than the street but the quality is often unsatisfactory. So regulatory bodies should pay heed to this situation. One of the thing which makes their livelihood very tough is the payment of extortion money. A significant amount of their hard earned money goes to the wrong hand. Despite many issues, we all should have a sympathetic viewpoint towards them and try to consider their contribution.

This study needed a lot of field visit. Hawkers usually are very busy. They don't intend to talk for a long time as they call for customers always and has to serve. There are not many hawkers who were interested to talk about how much they pay the bribe. Because there is fear of local authority, police, union and influential people. So, to obtain this data, much cases of negligence had to endure for months. We think, there are some scopes for further study.

\section{References}

Ahmed, T., \& Rahman, T. (2015). Non-Auditory Health Hazard Vulnerability to Noise Pollution: Assessing Public Awareness Gap. American Journal of Engineering Research (AJER), 4(4), 143-147.

Bhowmik, S. K. (2001). Hawkers in the Urban Informal Sector: A Study of Street Vendors in Seven Cities. $A$ Review, Economic and Political Weekly, 39(5), 1024-1027.

Bhowmik, S. K. (2003). National Policy for Street Vendors. Economic and Political Weekly, 38(16), 1543-46.

Bhowmik, S. K. (2005). Street Vendors in Asia: A Review. Economic and Political Weekly, 28(4), $2256-64$.

Bhowmik, S. K. (2010). Street Vendors in the Global Urban Economy. Economic and Political Weekly: A Review, 38(4), 2285-2290.

Bodhikong, K., \& Boonyarit, M. (2003). Case Study Report -Bangkok, Thailand Problems and Possible Solutions for Stall Sellers and Street Vendors, The Case of Stall Sellers and Street Vendors in front of Chulalongkorn Hospital.

Dendukuri, I. (2014). A Study of Street Vending Across the Globe. International Journal of Advanced Research in Computer Science and Software Engineering, 12(2), 514-519.

Diwakar, N., \& Anand, R. (2014). Economic Study on Women Street Vendors. New Man International Journal of Multidisciplinary Studies, 1(12), 132-133.

Diwakar, N., \& Anand, R. (2014). Socio-Economic Study on Women Street Vendors. New Men International Journal of Muntidispnerary Studies, 1(12), 125-132.

Hawkers seek rehab law from government. (2017, January 19). The Independent BD. Retrieved from http://www.theindependentbd.com/post/77176

Islam, S. M. (2015, March 8). Footpath vendors forced to pay Tk 850cr a year. The Daily Star. Retrieved from https://www.thedailystar.net/footpath-vendors-forced-to-pay-tk-850cr-a-year-17836

It's all for extortion. (2016, October 29). The Daily Star. Retrieved from https://www.thedailystar.net/frontpage/its-all-extortion-1306135

Matthias, O., \& Dada, O. (2013). A sociological investigation of the determinant factors and the effects of child street hawking in Nigeria. International Journal of Asian Social Science, 3(1):114-137.

Ministry of Urban Employment and Poverty Allevation, G. o. (2006). National Policy on Urban Street Vendors.

Nahar, N. (2016). Diseases And Health Condition of Street Hawker in Bangladesh.

Rabbi, A. R. (2017, June 19). Hawkers face ongoing extortion, lose Tk1.5cr a month. Dhaka Tribune. Retrieved from https://www.dhakatribune.com/bangladesh/dhaka/2017/06/19/hawkers-face-extortion-lose-tk1-5crmonth

Singh, N., \& Davar, S. C. (2004). Noise pollution-sources, effects and control. J. Human Ecology, 16(3), 181187.

Suraiya, S., \& Noor, F. (2012). An Analysis of Socioeconomic Conditions of Street Vendors: A Study on Dhaka City. DIU Research and Publication Archive. 